\title{
SOCial MEdia ANd Fabricated News DURING THE GEZI RIOTS
}

\section{BY GULIZAR HACIYAKUPOGLU}

The Gezi Protests began when a small group of activists held a sit-in at Gezi Park in Istanbul to call a halt to its demolition for building a shopping mall in its place. Justice and Development Party's (AKP) abrasive response to the protest, coupled with the police's intensive use of force against the demonstrators ignited the countrywide unrest which was motivated by environmental consciousness, exacerbated by police brutality, smoldered by the alleged provocation of domestic and foreign interest groups, and nourished by the progressive curtailment of civil liberties. The vehemence of the demonstrations caught the attention of the international media and reverberated in social media. However, it did not find reflection in Turkish mainstream media. In an atmosphere where mainstream media are silenced, censorship is common, and journalists are imprisoned, social media, as a less regulated, fast paced, rich information acquisition and dissemination tool, claimed its place in the demonstrations as the source of information and tool of citizen journalism. Social media, which have been a prominent ground for the discussion of sensitive topics that are rarely covered in mainstream media (e.g., the earthquake in the city of Van and the Reyhanli Bombings), emerged as the unfeigned alternative to the traditional media. ${ }^{1}$ Despite the advantages emanating from its purpose as the ultimate information source during the demonstrations, social media also functioned as an instrument of manipulation and provocation through the circulation of fabricated news. Impediments to the identification and verification of contrived news within the abundance of information, and governments use of social media for propagating its ideals and tracking counter opinions created a contention between the positive and negative employment of social media. With this in mind, the following paragraphs will espouse a critical approach to social media and confer the concerns on information abundance, dissemination of fabricated information, and social media's rise as an instrument of governance.

Social media was the prominent information source in the course of the riots. In fact, a recent poll conducted by the research and consultation organization KONDA on 4411 participants of Gezi demonstrations revealed that 69 percent of the activists heard about the protests from social media, and only 7 percent via TV. ${ }^{2}$ Thus, social media, primarily Facebook and Twitter, served

\footnotetext{
${ }^{1}$ Ozgur Uckan, “Gezi Sonrasi Sosyal Medya: Buyuk Birader'le Basa Cikmak”, interview by Sunay Gedik. Sol Portal, August 20, 2013, http://haber.sol.org.tr/devlet-ve-siyaset/gezi-sonrasi-sosyal-medya-buyuk-biraderle-basacikmak-haberi-78305

2 Bianet, "Konda's Gezi Resistance Poll”, June 13, 2013, http://www.bianet.org/english/youth/147543-94percent-of-gezi-resisters-participate-individually-poll-says
} 
as the main source of news on Gezi and the venue for sharing logistical information. Logistical information such as practical needs of the activists- including gas masks, location of the police, secure places to hide, wi-fi passwords around the demonstration sites- were among the most distributed messages. ${ }^{3}$ While this information indicated the urgency of the situation, the large volume of messages that emerged recalls Jodi Deans argument of fantasy of abundance. Fantasy of abundance stipulates that on the condition of the proliferation of new media, messages are more likely to stray or vanish as mere contributors to the circulation of content. ${ }^{4}$ Rapid and rich information flow leads to a decrease in the attention given to the quality and diversity of information, and makes accuracy and dependency of the online information a question. ${ }^{5}$ In the Gezi Riots, urgency of the messages, coupled with the emotional status of the public, encouraged people to circulate the information once acquired and arguably, this led to a decrease in the quality of information and increase in the dissemination of fictitious information. It became harder to locate the accurate information within vast amounts of knowledge, and the dilemma of urgency and sensitivity versus established verification led to the distribution of fabricated messages without confirming their accuracy.

Fabricated news distributed in the course of the riots can be analyzed under two main categories: those targeted towards provoking the activists, and those that were trumped up evidence supporting the government. Contrived information aiming to bait activists was oriented towards inciting demonstrators' emotions mainly via photo-shopped pictures, out of date images, or images of an incident recorded elsewhere in the world. Among many, the most striking ones were the false news that the supreme court would topple the government, if the demonstrations persevered for 48 hours; an image released of a person ran over by a tank when in reality it was footage from an accident abroad; images of people crossing the bridge on foot from the Asian to the European side of Istanbul served as the influx of demonstrators, which in reality was a picture from the 2012 Istanbul Marathon; and concocted news on the police's use of orange gas and real bullet. ${ }^{6}$ On the contrary, there were fictitious news vilifying Gezi protests and protestors.

The footage of the mosque that was used as an infirmary by voluntary doctors to treat activists who were subject to police brutality, and a shelter by the demonstrators absconding from the police attacks, were answered by the government with a plotted picture showing beer cans in the mosque. Comments released with the fabricated image accused protestors of disrespecting religion by drinking in the mosque and entering inside with their shoes. ${ }^{7}$ Government officials defended the accuracy of this information and declared that they would publicize a video showcasing the drinking, but this was never done. ${ }^{8}$ Whilst the Prime Minister relegated the

\footnotetext{
${ }^{3}$ Alkim Onar, “Gezi Parki Olaylarinda Sosyal Medyanin Etkisi”, Gazete Bilkent, June 16, 2013, http:/www.gazetebilkent.com/2013/06/16/gezi-parki-olaylarinda-sosyal-medyanin-etkisi/

${ }^{4}$ Jodi Dean, "Communicative Capitalism: Circulation and The Foreclosure of Politics", Cultural Politcs I, Issue I (2010): 53, 58 . http://commonconf.files.wordpress.com/2010/09/proofs-of-tech-fetish.pdf

5 Doris A. Graber, "The 'New' Media and Politics: What Does the Future Hold?", Political Science and Politics 29, 1 (1996): 35. http://www.jstor.org/stable/420188

${ }^{6}$ TimeTurk, “Gezi Parki’yla Ilgili Sosyal Medyada Dolasan 17 Yalan Haber”, June 2, 2013, http://www.timeturk.com/tr/2013/06/02/gezi-parki-yla-ilgili-sosyal-medyada-dolasan-17-yalan.html

7 Yilmaz, Mehmet, “Bir Provokasyonu Dile Dolamak”, Hurriyet, June 27, 2013, http://www.hurriyet.com.tr/yazarlar/23595307.asp

8 ibid.
} 
number of protestors to a small crowd of people, ${ }^{9}$ AKP's rally pictures were photo-shopped to make the venue look congested and the number of attendants to the party's rally at Kazlicesme (a district in Istanbul) was announced as over one million. ${ }^{10}$ However, it did not take long for this fabricated information to be refuted. Focused image of the picture exposed the duplicated images of attendees of the rally and as to the Kazlicesme rally, a group of academics calculated that the capacity of Kazlicesme could accommodate a maximum of five hundred thousand people. ${ }^{11}$ From the activist side, effects of the bombardment of fabricated news were mitigated to a certain degree via the designation and announcement of the factitious information by the more educated crowds, warnings on avoiding the circulation of false news, and sensitivity on eradicating disinformation.

There was almost a collective approach towards identifying false information. Sharing of the misinformation with warning, entering comments under fabricated materials to urge the one who shared it to remove it, and contacting people on the ground to verify the information were common approaches employed towards circumventing misinformation. ${ }^{12}$ The power of knowledge was not solely vested in social media or physically active demonstrators, but instead the strength came from the positive collaboration between the mutually dependent offline and online activism. Internet literacy, mainly the capacity to evaluate the accuracy of the information and make an educated judgment on which material to distribute, allowed the identification of photo-shopped images, outdated pictures, and other fictitious information. Educated approaches to the information facilitated the discovery of counterfeited information. Sensitivity on information accuracy increased the importance of real-time citizen journalism and collaborative compassion towards eliminating contrived information produced self-declared editors who corrected the false information they encountered online. Under these circumstances, eyewitness information gained importance and made the connection between online and physical participants more prominent. Internet literacy, experienced-based knowledge, and sensitivity on transmitting true information hampered the circulation of false information to a certain degree. However, abundance of information flow, differences in Internet literacy, hardship in identifying and warning every citizen who distributed a fabricated message, and of course well-executed cyber manipulation, made it impossible to halt the dissemination of inaccurate information. Furthermore, social media, as Spivak describes, acted as the poison and the medicine at the same time via its presence a cure to the activists' problems related to information acquisition, and existence as a poison facilitating provocation and the governments' identification of opposing opinions. ${ }^{13}$ Contrary to the increase in the number of Internet literate citizens, social media has granted the governments the opportunity to propagate their opinions in public, and track and target counter opinions. ${ }^{14}$

\footnotetext{
${ }^{9}$ Cumhuriyet, “Iran'dan Gul Icin Ilginc Iddia!”, July 13, 2013, http://www.cumhuriyet.com.tr/?hn=428548

${ }^{10}$ Gulen, Ali, "Photoshop 'lu Miting Avrupa Basininda", Sozcu, June 12, 2013, http://sozcu.com.tr/2013/dunya/photoshoplu-miting-avrupa-basininda-312955/

${ }^{11}$ Milliyet, “Bogazici'li Akademisyenler Kazlicesme'deki Katilimci Sayisini Hesapladi”, June 17, 2013, http://siyaset.milliyet.com.tr/bogazici-li-akademisyenler/siyaset/detay/1723986/default.htm

12 Aktuel, "Sosyal Medyada Bu Kez Eve Donus Ruzgari", June 4, 2013, http://www.aktuel.com.tr/Medya/2013/06/04/eve-donuyoruz

${ }^{13}$ Geert Lovink, "Pax Electronica: Against Crisis-driven Global Telecommunication: An Interview with Gayatri Spivak", http://www.kunstradio.at/FUTURE/DX/EVENTS/geert-spivak.html

${ }^{14}$ Evegeny Morozov, "The Net Delusion: The Dark Side of the Internet Revolution", (USA: Public Affairs, 2011), 82 , http://digitalmediafys.pbworks.com/w/file/fetch/47763349/MorozovChpsIntroToFourNetDelusion2011.pdf
} 
The AKP government demonstrated a poor execution of social media management during the most intense times of the Gezi demonstrations. However, as mentioned earlier, they used it for propagative purposes, and as will be elucidated in the following paragraph, they benefitted from social media through the ability to track counter-opinions. Twitter gave officials the opportunity to locate opposing ideas and use written logs as evidence. Citizens, including acclaimed journalists, students, actors and actresses, have been taken into custody because of their tweets in support of Gezi and online archive of their Twitter messages were used as evidences against them. ${ }^{15}$ While tracking counter opinions made social media an indispensible tool for the government, cyberspace's emergence as a political ground initiated the attempt to make it a state apparatus. AKP's recruitment of 6,000 people to assist the party's social media management ${ }^{16}$ confirmed the party's acknowledgment of the social media as a political arena and signaled an aspiration to take full advantage of social media for promotional and tracking purposes, as well as sociological research. The Research and Development Department of the AK Party issued a comprehensive report on social media practices during the Gezi demonstrations. ${ }^{17}$ Twitter was the highlight of the report, according to the Department's study, as it was the most widely used tool during the period of the demonstrations. ${ }^{18}$ To provide a brief overview on Twitter use during the riots, the number of active Turkish Twitter users increased from 1 million 800 thousand on May 29, 2013, the day before the riots, to more than 9 million 500 thousand users on June 10, 2013. ${ }^{19}$ On May 31, 2013, the day the riots reached their climax, 15 Million 247 thousand messages were tweeted. ${ }^{20}$ In this regard, it was not surprising for the AK Party government to conduct research on the tool that grants the citizens organizational power and look for ways to utilize the tool for the benefit of the government. AK Party's social media report encapsulated detailed information on social media usage, fabricated news, posts of opinion leaders, and recommendations to the party members on social media usage. Party members were recommended to tweet original and candid messages to pull the popular masses, were advised not to embrace a parental attitude and be peremptory towards teenagers, and were instructed to wait for nine minutes if they were angered by criticisms to avoid responding harshly. ${ }^{21}$ As social media and other Internet engagement are accepted as a site of political battle, which is not entirely possible to obstruct, enhancement in social media practices for governmental purposes is a common strategy.

Months after the effervescent physical protests, aftershocks still keep the Gezi spirit alive and remind AKP government that the citizens will not take everything for granted and are willing to protect their rights. Although the government continues to track counter opinions, file lawsuits

\footnotetext{
15 Milliyet, “Twitter Mesajlarina Orgut Sorusturmasi”, June 07, 2013, http://gundem.milliyet.com.tr/twittermesajlarina-orgut/gundem/detay/1719250/default.htm

Gokce Diner, “Gazeteci Tayfun Talipoglu’na 'Gezi' Sorusturmasi”, Hurriyet, July 19, 2013, http://www.hurriyet.com.tr/gundem/23760077.asp

${ }^{16}$ Albayrak, A \& Parkinson, J., “Turkey's Government Forms 6,000-Member Social Media Team”, The Wallstreet Journal, Sept. 16, 2013, http://online.wsj.com/news/articles/SB10001424127887323527004579079151479634742

${ }^{17}$ CNN Turk, “Ak Parti'ye "Gezi Parki Sosyal Medya Raporu”,, July 1, 2013, https://www.cnnturk.com/2013/turkiye/07/01/ak.partiye.gezi.parki.sosyal.medya.raporu/713725.0/index.html 18 ibid.

${ }^{19}$ Serdar Kuzuloglu, “Gezi Parki Eylemlerinin Sosyal Medya Karnesi”, Radikal, June 19, 2013, http://www.radikal.com.tr/yazarlar/m_serdar_kuzuloglu/gezi_parki_eylemlerinin_sosyal_medya_karnesi-1138146

${ }^{20}$ Alkim Onar, "Gezi Parki Olaylarinda Sosyal Medyanin Etkisi”, Gazete Bilkent, June 16, 2013, http://www.gazetebilkent.com/2013/06/16/gezi-parki-olaylarinda-sosyal-medyanin-etkisi/ 21 ibid.
} 
based on commentaries made on the Internet and connect almost every political controversy to Gezi Riots, citizens still use the Internet to deliberate on political issues, organize demonstrations, disseminate information and conduct citizen journalism despite the risk of being tracked and arrested for their anti-government entries. While the diffusion of fabricated news, and obstructions to their verification persevere, Internet-literate citizens are becoming more conscious of the existence of fictitious information online, spending more effort in locating correct information within the abundant knowledge online, and warning less experienced users regarding false information. The battle between positive and negative impacts of the Internet, and its existence as an instrument of governance as well as a tool for creating informed citizens, will persist. Nevertheless, increase in awareness of the negative and positive uses of the Net may take citizens a step further. The Gezi Riots not only installed this cognizance in Turkish citizens, but also demonstrated that protests can still flourish in an atmosphere where the mainstream media is silenced and the Internet can be a poison and a medicine at the same time. 
1. Aktuel. "Sosyal Medyada Bu Kez Eve Donus Ruzgari". June 4, 2013. http://www.aktuel.com.tr/Medya/2013/06/04/eve-donuyoruz

2. Albayrak, A \& Parkinson, J., “Turkey's Government Forms 6,000-Member Social Media Team”, The Wallstreet Journal, Sept. 16, 2013, http://online.wsj.com/news/articles/SB10001424127887323527004579079151479634742

3. Bianet. "Konda's Gezi Resistance Poll". June 13, 2013. http://www.bianet.org/english/youth/147543-94-percent-of-gezi-resisters-participateindividually-poll-says

4. CNN Turk. "AK Parti'ye "Gezi Parki Sosyal Medya Raporu”". July 1, 2013. https://www.cnnturk.com/2013/turkiye/07/01/ak.partiye.gezi.parki.sosyal.medya.raporu/7 13725.0/index.html

5. Cumhuriyet. "Iran'dan Gul Icin Ilginc Iddia!". July 13, 2013. http://www.cumhuriyet.com.tr/?hn=428548

6. Diner, Gokce. "Gazeteci Tayfun Talipoglu'na 'Gezi' Sorusturmasi”. Hurriyet, July 19, 2013. http://www.hurriyet.com.tr/gundem/23760077.asp

7. Graber, Doris A.. "The 'New' Media and Politics: What Does the Future Hold?". Political Science and Politics 29, 1 (1996): 35. http://www.jstor.org/stable/420188

8. Gulen, Ali, “Photoshop'lu Miting Avrupa Basininda", Sozcu, June 12, 2013, http://sozcu.com.tr/2013/dunya/photoshoplu-miting-avrupa-basininda-312955/

9. Kuzuloglu, Serdar. "Gezi Parki Eylemlerinin Sosyal Medya Karnesi”. Radikal, June 19, 2013.

http://www.radikal.com.tr/yazarlar/m_serdar_kuzuloglu/gezi_parki_eylemlerinin_sosyal medya karnesi-1138146

10. Lovink, Geert. "Pax Electronica: Against Crisis-driven Global Telecommunication: An Interview with Gayatri Spivak". http://www.kunstradio.at/FUTURE/DX/EVENTS/geertspivak.html

11. Milliyet. "Bogazici'li Akademisyenler Kazlicesme'deki Katilimci Sayisini Hesapladi". June $\quad 17, \quad 2013 . \quad$ http://siyaset.milliyet.com.tr/bogazici-liakademisyenler/siyaset/detay/1723986/default.htm

12. Milliyet. "Twitter Mesajlarina Orgut Sorusturmasi". June 07, 2013. http://gundem.milliyet.com.tr/twitter-mesajlarinaorgut/gundem/detay/1719250/default.htm

13. Morozov, Evegeny. "The Net Delusion: The Dark Side of the Internet Revolution". USA: Public Affairs, 2011 , 82. http://digitalmediafys.pbworks.com/w/file/fetch/47763349/MorozovChpsIntroToFourNet Delusion2011.pdf

14. Onar, Alkim. "Gezi Parki Olaylarinda Sosyal Medyanin Etkisi". Gazete Bilkent, June 16, 2013. medyanin-etkisi/

15. TimeTurk. "Gezi Parki'yla Ilgili Sosyal Medyada Dolasan 17 Yalan Haber". June 2, 2013. http://www.timeturk.com/tr/2013/06/02/gezi-parki-yla-ilgili-sosyal-medyadadolasan-17-yalan.html

16. Uckan, Ozgur. "Gezi Sonrasi Sosyal Medya: Buyuk Birader'le Basa Cikmak". Interview by Sunay Gedik. Sol Portal, August 20, 2013. http://haber.sol.org.tr/devlet-vesiyaset/gezi-sonrasi-sosyal-medya-buyuk-biraderle-basa-cikmak-haberi-78305

17. Yilmaz, Mehmet. "Bir Provokasyonu Dile Dolamak". Hurriyet, June 27, 2013, http://www.hurriyet.com.tr/yazarlar/23595307.asp 
MEI INSIGHT NO. 108

12 MARCH 2014

(C), MEI Singapore 2013.

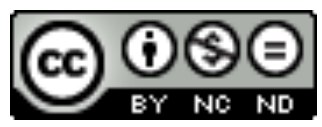

